Dhaka Univ. J. Bio. Sci. 19(1): 73-81, 2010 (January)

\title{
MICROBIAL LOAD IN TANNERY AND TEXTILE EFFLUENTS AND THEIR RECEIVING RIVERS OF DHAKA
}

\author{
Monika Das, Md. Kawser Ahmed*, Fauzia Begum ${ }^{1}$, Sahana Parveen ${ }^{1}$ \\ Md. Monirul Islam and Mahmuda Begum ${ }^{2}$ \\ Department of Fisheries, University of Dhaka, Dhaka-1000, Bangladesh
}

Key words: Microbial load, Tannery, Textile effluents, Receiving rivers

\begin{abstract}
The present study was undertaken to investigate the occurrence of some selected microorganisms in industrial effluents and in the river Buriganga and Karnatoli, which receive the industrial effluents directly from industries, with a view to evaluate the effect of industrial effluents on river. The total viable bacterial count (TVBC) in both tannery and textile effluents were slightly higher in dry season than those of rainy and summer. The TVBC in Buriganga River ranged from $3.4 \times 10^{5}$ to $9.6 \times 10^{5}, 2.2 \times 10^{4}$ to $1.2 \times 10^{5}$ and $7.2 \times 10^{4}$ to $4.5 \times 10^{5} \mathrm{cfu} / \mathrm{ml}$ in dry, rainy and summer seasons, respectively, and the TVBC in Karnatoli River ranged from $4.9 \times 10^{5}$ to $5.4 \times 10^{6}, 1.2 \times 10^{5}$ to $1.0 \times 10^{5}$ and $5.3 \times 10^{4}$ to $3.8 \times 10^{5} \mathrm{cfu} / \mathrm{ml}$ in dry, rainy and summer seasons, respectively. Pseudomonas spp. in effluents and river water were also slightly higher in dry season than that of rainy and summer seasons due to increase in water level. The total coliform and fecal coliform counts of the industrial effluents and discharge point in the river were always very high, which was $>2.4 \times 10^{3} \mathrm{cfu} / 100 \mathrm{ml}$ in all seasons as measured by the MPN method. Salmonella, Vibrio and Staphylococcus were frequently isolated from all the sampling points throughout the year with a few exceptions. This study indicates that the water of the river Buriganga and Karnatoli is heavily contaminated with both industrial wastes and domestic sewage materials. The bacteriological state of the water of the rivers is comparable to that of the effluents. The presence of pathogenic organisms may pose health hazards to the users of the river water and also poses risks for the aquatic organisms especially fish of the water bodies.
\end{abstract}

\section{Introduction}

The industrial areas in Bangladesh are situated in the midst of densely populated regions. There are many hazardous and potentially dangerous polluting industries situated in the cities of Bangladesh. Industrial units are mostly located along the banks of the rivers. There are obvious reasons for this such as provision of transportation for incoming raw materials and outgoing finished products.(1) These

*Corresponding author: <kawser_du@yahoo.com>. ${ }^{1}$ Institute of Food Science \& Technology, Bangladesh Council for Scientific and Industrial Research, Dhaka-1205, Bangladesh. 2Department of Zoology, University of Dhaka, Dhaka-1000, Bangladesh. 
industries have limited effluent processing arrangement. The impact of water pollutants on the environment depends on the quantity of pollutants discharged and on their physico-chemical characteristics. Industrial pollution is an area of growing environmental concern in Bangladesh like many other countries of the world. Hence, the imported resource based industries such as tanneries, pharmaceuticals, textiles, plastics, petroleum refineries and metal works are considered as highly polluting. (2)

An industry uses a large quantity of water in its production unit either as raw material or in process control or for both. A little quantity of water is absorbed and the rest comes out as waste. This waste contains various contaminants, which are organic and inorganic in nature and are discharged directly into the surface water with or without any treatment. The dumping of effluents into an aquatic body can seriously affect its flora, fauna and abiotic components. The major effects of the toxic discharge on aquatic fauna and water quality are the fish death and contamination of water by heavy metals. ${ }^{(3)}$

Textile and dying industrial effluents offer the alteration of physical, chemical, and biological properties of aquatic environment by counting change in temperature, odor, noise, and turbidity are the original properties that is harmful to public health, livestock, wildlife, fish and other biodiversity. ${ }^{(4)}$

The present status of water pollution of Bangladesh is increasing at an alarming rate. Discharge from various anthropogenic activities badly affects the aquatic environment.(1) Aquatic plants and animals are seriously affected due to the deterioration of water quality. The industrial effluents contain large numbers of heterotrophic bacteria, organic matter and a source of pathogenic bacteria. The Buriganga River is greatly affected by the discharge of these effluents. (2)

Microorganisms, particularly those growing as biofilms, meet all of these criteria and are also an important source of food within rivers. Within riverine systems, microbial aggregates and biofilms are important in terms of fundamental processes, such as biogeochemical cycling and biodegradation activity. Hence, these communities represent excellent potential indicators of changes in ecosystem health.

Although a great deal of work has been carried out in developed countries on the detection of pollution of open water bodies but no recent information is available on this aspect in the field level of Bangladesh. The increase in the interest in the microbial ecology of aquatic environment in recent years, it is important to have an understanding of the natural, or authochthonus, microbial flora in aquatic ecosystem, as a result it was considered useful to determine the prevalence of some selected microbes in some industrial effluents and their adjacent rivers. 
The objectives of this study were to assess the total bacterial load, harmful bacteria, yeasts and molds in the effluents released from tannery and textile industry and receiving rivers where these effluents are discharged.

\section{Materials and Methods}

The present study was carried out during August, 2006 to August, 2007. Within this period, water samples were collected at two months interval in the morning 8.00 - 9.00 a.m. Samples were collected from three stations from both the two industries of Dhaka City: Tannery (Nur Bhai Tannery, Rayer Bazar) and Textile (Doyel-Complex, Savar). In addition to the discharge pipes of the above industries the water samples were collected from Buriganga and Karnatoli Rivers where effluent was discharged. The study sites included effluents discharge from tannery through discharge pipe (Ta1), water from tannery discharged point into the river near Sikder Medical College, Rayer bazar (Ta2), water from river Buriganga near Gabtoli (Ta3), effluents discharge from textile through discharge pipe (Te1), water from textile discharged point into the river Karnatoli (Te2) and water from river Karnatoli near Mirpur (Te3).

At each station water sample was taken in sterilized glass bottle for microbial analysis. The bottle was grasped at the base with one hand and plunged the bottle mouth down into the water to avoid introducing surface scum. The mouth of the bottle was positioned into the current away from the hand. The sampling depth was $15-30 \mathrm{~cm}$ below the water surface. After removal of the bottle from the water, poured out a small portion of the sample to allow air space of $2.5-5 \mathrm{~cm}$ above each sample for proper mixing of the sample before analysis. Then the bottles were transferred to laboratory. Temperature of the water was measured through mercury thermometer $\left({ }^{\circ} \mathrm{C}\right)$ on the spot. The samples were transported in an icebox with sufficient ice blocks to maintain the temperature around $4-6^{\circ} \mathrm{C}$. The samples were then stored at $4^{\circ} \mathrm{C}$ at the refrigerator in the laboratory until use.

Bacteriological analyses: The heterotrophic bacteria were counted by the pourplate technique by using PCA agar. Total Pseudomonas was counted by pour-plate technique and confirmed by oxidase-catalase test. The total coliform and fecal coliform bacteria were enumerated by MPN procedures. Nucleated and metalic shining colonies in eosin methylene blue (EMB) agar plates were suspected as $E$. coli and IMViC tests were done to differentiate $E$. coli from other coliforms. Salmonella was enriched and isolated from the sample waters by the method described by APHA. ${ }^{(5)}$ Staphylococcus was isolated and enumerated by using Baird Parker agar. Alkaline peptone water (APW) was used commonly for enrichment and isolation of Vibrio. TCBS agar was also used for plating and incubating the microorganism. 
Biochemical tests (oxidase-catalase) were made to identify the presence of Vibrio sp. in the samples.

\section{Results and Discussion}

Total viable bacterial count (TBVC) is one of the important parameters for determining water quality. Total bacteria deplete oxygen immediately down from input of the effluent.(6) The total bacterial count of receiving water can provide extremely valuable statistics in monitoring various types of pollutants. Further, it must be realized that the data are significant not as absolute measure but as relative values to be compared in space and time.

The TVBC of different sampling stations is presented in Table 1 . The highest load of total viable bacteria $\left(7.2 \times 10^{6} \mathrm{cfu} / \mathrm{ml}\right)$ was found in tannery effluents during dry season just after Eid-ul-Azha due to increase tanning waste and minimum $(2.2 \times$ $10^{4} \mathrm{cfu} / \mathrm{ml}$ ) was found in Buriganga River near Gabtoli during rainy season. These variations of bacterial loads from locations to locations and river to river may be correlated with the flow of the rivers and location of industries and their waste disposal system. The high bacterial load of tannery and textile wastes indicates that a huge amount of bacteria was present in water and deteriorated the water quality in a great extent.

Table 1. Seasonal variations of total bacterial load at different sampling stations of industrial effluent and receiving rivers of Dhaka.

\begin{tabular}{cccc}
\hline \multirow{2}{*}{$\begin{array}{c}\text { Sampling } \\
\text { station }\end{array}$} & \multicolumn{3}{c}{ TVBC $(\mathrm{cfu} / \mathrm{ml})$} \\
\cline { 2 - 4 } & Dry & Rainy & Summer \\
\hline Ta1 & $7.2 \times 10^{6}$ & $1.9 \times 10^{6}$ & $4.2 \times 10^{6}$ \\
Ta2 & $9.6 \times 10^{5}$ & $1.2 \times 10^{5}$ & $4.5 \times 10^{5}$ \\
Ta3 & $3.4 \times 10^{5}$ & $2.2 \times 10^{4}$ & $7.2 \times 10^{4}$ \\
Te1 & $5.8 \times 10^{6}$ & $3.5 \times 10^{6}$ & $5.4 \times 10^{6}$ \\
Te2 & $5.4 \times 10^{6}$ & $1.0 \times 10^{5}$ & $3.8 \times 10^{5}$ \\
Te3 & $4.9 \times 10^{5}$ & $1.2 \times 10^{5}$ & $5.3 \times 10^{4}$ \\
\hline
\end{tabular}

Previous work showed that the amount of heterotropic bacteria varied from $1.1 \times$ $10^{5}$ to $2.98 \times 10^{9} \mathrm{cfu} / \mathrm{ml}$ in the Buriganga river, ${ }^{(7)}$ which agree with the present result. Boyd $^{(8)}$ found that abnormal microbial properties affect the total water body and aquaculture system. It was already reported that high amount of bacteria in environment gives high load to the organisms. ${ }^{(9)}$ So, the presence of higher number of bacteria in tannery and textile pollutes aquatic environment that might create severe injury to fish and other aquatic life. 
Pseudomonas is important in the balance of nature and also in the economy of human affairs. It is globally active in aerobic decomposition and biodegradation, and hence, they play a key role in the carbon cycle. Pseudomonas species are renowned for their abilities to degrade compounds, which are highly refractory to other organisms, including aliphatic and aromatic hydrocarbons, fatty acids, insecticides and other environmental pollutants. Pseudomonads are also a regular component of microbial food spoilage in the field, in the market place, and in the home.(10) The highest load of Pseudomonas spp. $\left(5.4 \times 10^{7} \mathrm{cfu} / \mathrm{ml}\right)$ of tannery waste samples was found in effluents during dry season and minimum $\left(9.6 \times 10^{4} \mathrm{cfu} / \mathrm{ml}\right)$ was in Buriganga River during rainy season. In case of textile waste samples, maximum load $\left(5.4 \times 10^{6} \mathrm{cfu} / \mathrm{ml}\right)$ was found in effluents during rainy season and minimum $(3.8 \mathrm{x}$ $10^{4} \mathrm{cfu} / \mathrm{ml}$ ) was in Karnatoli River during dry season (Table 2).

Table 2. Seasonal variations of pseudomonads at different sampling stations of industrial effluent and receiving rivers of Dhaka.

\begin{tabular}{cccc}
\hline \multirow{2}{*}{$\begin{array}{c}\text { Sampling } \\
\text { station }\end{array}$} & \multicolumn{3}{c}{ Total Pseudomonas $(\mathrm{cfu} / \mathrm{ml})$} \\
\cline { 2 - 4 } & Dry & Rainy & Summer \\
\hline $\mathrm{Ta} 1$ & $5.4 \times 10^{7}$ & $1.0 \times 10^{7}$ & $4.8 \times 10^{6}$ \\
$\mathrm{Ta} 2$ & $6.8 \times 10^{6}$ & $1.4 \times 10^{6}$ & $5.7 \times 10^{5}$ \\
$\mathrm{Ta} 3$ & $3.5 \times 10^{5}$ & $2.7 \times 10^{5}$ & $6.8 \times 10^{5}$ \\
$\mathrm{Te} 1$ & $4.8 \times 10^{6}$ & $5.4 \times 10^{6}$ & $4.9 \times 10^{6}$ \\
$\mathrm{Te} 2$ & $3.6 \times 10^{6}$ & $7.5 \times 10^{5}$ & $5.8 \times 10^{5}$ \\
$\mathrm{Te} 3$ & $2.2 \times 10^{5}$ & $5.2 \times 10^{5}$ & $4.8 \times 10^{5}$ \\
\hline
\end{tabular}

Yeast is also one of the microbial parameters of water that can indicate the deterioration of the quality of water. The presence of yeast indicates the pollution of water. $^{(5)}$ In the present study, the highest load $\left(5.7 \times 10^{1} \mathrm{cfu} / \mathrm{ml}\right)$ of yeast in tannery waste samples was found in effluents during dry season and minimum was $1.5 \times 10^{1}$ $\mathrm{cfu} / \mathrm{ml}$ in Buriganga river water near Gabtoli during rainy season. In textile waste samples, maximum load $\left(5.5 \times 10^{1} \mathrm{cfu} / \mathrm{ml}\right)$ was found in effluents during dry season and minimum load was $1.8 \times 10^{1} \mathrm{cfu} / \mathrm{ml}$ in downstream of Karnatoli River during rainy season (Table 3 ).

Mold is also an important microbial parameter for determining water quality. The presence of mold indicates the deterioration of water quality because no fungus will be present in safe water for consumption of humans and others. ${ }^{(5)}$ In this study, the highest load of mold $\left(4.0 \times 10^{1} \mathrm{cfu} / \mathrm{ml}\right)$ in tannery waste samples was found in effluents during dry season and minimum load $\left(1.1 \times 10^{1} \mathrm{cfu} / \mathrm{ml}\right)$ was in effluents during November. In case of textile waste samples, maximum load $\left(7.2 \times 10^{1} \mathrm{cfu} / \mathrm{ml}\right)$ was found in effluents during dry season and minimum fungal load $\left(0.6 \times 10^{1} \mathrm{cfu} / \mathrm{ml}\right)$ 
was during rainy season (Table 3). The presence of mold in the all samples designates the samples are microbially polluted.

Table 3. Seasonal variations of yeast and mold count at different sampling stations of industrial effluent and receiving rivers of Dhaka.

\begin{tabular}{cccccccc}
\hline \multirow{2}{*}{$\begin{array}{c}\text { Sampling } \\
\text { station }\end{array}$} & \multicolumn{3}{c}{ Yeast $(\mathrm{cfu} / \mathrm{ml})$} & & \multicolumn{3}{c}{ Mold $(\mathrm{cfu} / \mathrm{ml})$} \\
\cline { 2 - 3 } \cline { 6 - 7 } Ta1 & Dry & Rainy & Summer & & Dry & Rainy & Summer \\
\hline Ta2 & 50 & 44 & 41 & & 40 & 37 & 26 \\
Ta3 & 26 & 25 & 34 & & 31 & 27 & 22 \\
Te1 & 55 & 49 & 20 & & 21 & 16 & 18 \\
Te2 & 44 & 26 & 50 & & 72 & 66 & 48 \\
Te3 & 28 & 20 & 23 & & 48 & 28 & 36 \\
\hline
\end{tabular}

Coliform group of bacteria is one of the most important microbial parameter for determining the quality of water. Coliform is an effective indicator of fecal pollution of water. The total coliform was found greater than $2.4 \times 10^{3 / 100 ~} \mathrm{ml}$ in all the samples during the study period (Table 4). The high coliform count throughout the year indicates that the water bodies are continually contaminated by fecal material too. Hasan et al. ${ }^{(6)}$ found the coliform count as $>2.4 \times 10^{3} / 100 \mathrm{ml}$ in sewage lagoon and the counts at different point of the Buriganga River water varied from $1.1 \times 10^{3}$ to $>2.4 \times 10^{3} / 100 \mathrm{ml}$. Their results are in agreement with the present investigation.

Table 4. Seasonal variations of coliform and fecal coliform count (MPN) at different sampling stations of industrial effluent and receiving rivers of Dhaka.

\begin{tabular}{|c|c|c|c|c|c|c|}
\hline \multirow{2}{*}{$\begin{array}{l}\text { Sampling } \\
\text { station }\end{array}$} & \multicolumn{3}{|c|}{ Total coliform $/ 100 \mathrm{ml}$} & \multicolumn{3}{|c|}{ Total fecal coliform/100 ml } \\
\hline & Dry & Rainy & Summer & Dry & Rainy & Summer \\
\hline Ta1 & $>2.4 \times 10^{3}$ & $>2.4 \times 10^{3}$ & $>2.4 \times 10^{3}$ & $>2.4 \times 10^{3}$ & $>2.4 \times 10^{3}$ & $>2.4 \times 10^{3}$ \\
\hline $\mathrm{Ta} 2$ & $>2.4 \times 10^{3}$ & $>2.4 \times 10^{3}$ & $>2.4 \times 10^{3}$ & $>2.4 \times 10^{3}$ & $>2.4 \times 10^{3}$ & $>2.4 \times 10^{3}$ \\
\hline Ta3 & $>2.4 \times 10^{3}$ & $>2.4 \times 10^{3}$ & $>2.4 \times 10^{3}$ & $>2.4 \times 10^{3}$ & $2.1 \times 10^{2}$ & $2.1 \times 10^{2}$ \\
\hline Te1 & $>2.4 \times 10^{3}$ & $>2.4 \times 10^{3}$ & $>2.4 \times 10^{3}$ & $>2.4 \times 10^{3}$ & $>2.4 \times 10^{3}$ & $>2.4 \times 10^{3}$ \\
\hline Te2 & $>2.4 \times 10^{3}$ & $>2.4 \times 10^{3}$ & $>2.4 \times 10^{3}$ & $>2.4 \times 10^{3}$ & $1.1 \times 10^{3}$ & $>2.4 \times 10^{3}$ \\
\hline Te3 & $>2.4 \times 10^{3}$ & $>2.4 \times 10^{3}$ & $>2.4 \times 10^{3}$ & $>2.4 \times 10^{3}$ & $2.8 \times 10^{1}$ & $4.6 \times 10^{2}$ \\
\hline
\end{tabular}

The fecal coliform load of tannery waste samples ranged from $2.1 \times 10^{2} / 100 \mathrm{ml}$ to $>2.4 \times 10^{3 / 100} \mathrm{ml}$. In case of textile waste samples the fecal coliform load ranged from

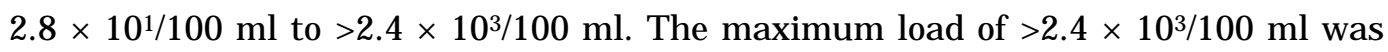
found in all effluent throughout the year and minimum load of $2.8 \times 10^{1 / 100 ~ m l ~ w a s ~}$ found in river water during rainy season (Table 4). The result indicates that the river water is not only contaminated by industrial pollutants but fecal pollution also takes place. 
Hasan et al. ${ }^{(7)}$ found the fecal coliform bacteria in sewage as $>2.4 \times 10^{3 / 100 ~ m l}$ and its counts of the outfall point and the other location of Buriganga River varied from $1.1 \times 10^{3 / 100 ~} \mathrm{ml}$ to $>2.4 \times 10^{3 / 100} \mathrm{ml}$. The above investigation agrees with present studies. The US Department of Interior Federal Water Pollution Control Administration in its 1968 report on water quality stated the tolerable limit for recreation purposes up to $2.0 \times 10^{2} / 100 \mathrm{ml}$ of fecal coliforms. World Health Organization allows less than 10 coliforms per $100 \mathrm{ml}$ as maximum for small community supplies. In this observation total and fecal coliform counts in all the sampling stations are greater than the recommended standards, which indicate higher level of pollution.

Salmonella spp. are also important indicators of water pollution. During the study period Salmonella was present almost all times in all the samples (Table 5). Salmonella spp. are of great concern in public health and are explained as a prime example of shellfish transmitted pathogen.(11) It has been suggested that enteric pathogens can frequently become associated with aquatic animals ranging from microscopic invertebrates to aquatic mammals. ${ }^{(12)}$ The results of the present study are similar to that of the study performed by Dondero et al.(13) who isolated Salmonella spp. from streams and lakes. Cherry et al.(14) also distinguished Salmonella as an index of pollution of surface water. For that reason the Buriganga River and Karnatoli River may be distinguished as very much contaminated. Bhuiyan $^{(15)}$ reported that water pollution is one of the main causes, which inhibits the proper growth of fish and also kill the fish, ultimately decreasing fish production.

Table 5. Occurance of pathogenic bacteria at different sampling stations of industrial effluent and receiving rivers of Dhaka.

\begin{tabular}{|c|c|c|c|c|c|c|c|c|c|}
\hline \multirow{2}{*}{$\begin{array}{l}\text { Sampling } \\
\text { station }\end{array}$} & \multicolumn{3}{|c|}{ Salmonella sp. } & \multicolumn{3}{|c|}{ Staphyllococcus sp. } & \multicolumn{3}{|c|}{ Vibrio sp. } \\
\hline & Dry & Rainy & Summer & Dry & Rainy & Summer & Dry & Rainy & Summer \\
\hline Ta1 & + & + & + & + & + & + & + & + & + \\
\hline Ta2 & + & + & + & - & + & + & - & + & + \\
\hline Ta3 & + & + & + & + & + & + & + & - & + \\
\hline Te1 & + & + & + & + & + & + & + & + & + \\
\hline $\mathrm{Te} 2$ & + & + & + & + & + & + & + & + & + \\
\hline Te3 & + & + & + & + & + & - & + & + & - \\
\hline
\end{tabular}

Staphylococcus is highly vulnerable to destruction by heat treatment and nearly all sanitizing agents. Thus, the presence of this bacterium or its enterotoxins in processed foods or on food processing equipment is generally an indication of poor sanitation. Staphylococcus can cause severe food poisoning. It has been identified as the causative agent in many food poisoning outbreaks and is probably responsible for even more cases in individuals and family groups than the records show. During the study period Staphylococcus was present almost always in the water samples (Table 5 ). These results indicate that the water of the river is highly polluted. 
Vibrio is the indicator of fecal pollution that was isolated from most of the water samples (Table 5). It indicates that the water of the river Buriganga and Karnatoli are polluted by industrial wastes, as well as by domestic or sewage material. Vibrios are ubiquitous abundant in the aquatic environment.(16-17) and river water can be great source of transmission of vibrios into aquatic organisms. ${ }^{(12)}$ Temperature has been found to be a major factor in both the seasonal and geographical distribution of Vibrio parahaemolyticus in shellfish-growing areas of the temperate region.(18) Deepanjali et al.(19) also showed that seasonal variation in abundance of total and pathogenic Vibrio parahaemolyticus bacteria in oysters along the Southwest Coast of India.

It is found that seasonal variation is a factor in microbial distribution, which agrees with Neumann et al. ${ }^{(20)}$ who found that in tropical countries the seasonal cycle of the organism is correlated with the rainy and dry seasons; the lowest numbers are found in rainy months, and the highest numbers are found in the dry season.

It is evident from the present study that the river bodies are highly contaminated regardless of season by bacteria. Presence of coliforms indicates fecal contamination. High bacterial load indicates that the water bodies contain huge amount of organic pollutants. Bacterial load and presence of pathogenic organisms are comparable in both effluent and river water.

\section{References}

1. Alam K 2004. Cleanup of the Buriganga River: Integrating the environment into decisionmaking. Ph. D. Dissertation, Murdoch University, Western Australia.

2. Islam F, R Shammin and J Junait 1997. A detailed analysis on industrial pollution in Bangladesh. Workshop Discussion Paper, The World Bank Dhaka Office; Dhaka.

3. Goutam A, VP Joshi and OP Semwal 1992. Industrial Effluent and Aquatic Pollution in Aquatic Environment. Ashish Publishing House, New Delhi, pp. 48-57.

4. Huq A, RR Colwell, R Rahman, A Ali, MAR Chawdhury, S Parveen, DA Sack and CE Russek 1980. Detection of Vibrio cholerae 01 in the aquatic environment by flurescent monoclonal antibody and cultural methods. Appl. Environ. Microbiol 56(8): 270-273.

5. APHA (American Public Health Association) 1998. Standard Methods for the Examination of Water and Wastewater (20th ed). (Eds: Greenberg AE, Clesceri LS and Eaton AD eds). Washington DC.

6. Garnier J, P Servais and G Billen 1991. Bacterioplankton in the Seine River: Impact of the Parisian urban effluents. Can. J. Microbiol. 38:56-64.

7. Hasan MM, MK Ahmed, F Hafiz, AMI Hussain, S Parveen and S Rahman 2006. Load of heterotrophic and nitrifying bacteria in the sewage lagoon and the receiving river Buriganga. Bangladesh J. Microbiol. 23(2): 93-97.

8. Boyd CE 1982. Water Quality Management for Pond Fish Culture. Elsevier Science Publication, Armsterdam, pp. 318. 
9. Rhodes MW and H Kator 1988. Survival of Escherichia coli and Salmonella spp. in estuarine environments. Appl. Environ. Microbiol. 54(12): 2902-2907.

10. Todar K 2004. Todar's Online Textbook of Bacteriology. University of WisconsinMadison, Madison.

11. Baudart J, J Grabulos, JP Barusseau and P Lebaron 2000. Salmonella spp. and faecal coliform loads in coastal waters from a point vs non-point source of pollution. J. Environ. Qual. 29: 241-250.

12. Venkateswaran K, T Takai, IM Navarro, H Nakano, H Hashimoto and RJ Siebling 1989. Ecology of Vibrio cholerae non-O1 and Salmonella spp. and role of zooplankton in their seasonal distribution in Fukuyama coastal waters, Japan. Appl. Environ. Microbiol. 55: 1591-1598.

13. Dondero NC, CT Thomas, M Khare, JF Timoney and GM Fukoi 2001. Salmonella in surface waters of Central New York State. Appl. Microbiol. 33(4): 791-801.

14. Cherry WB, JB Hanka, BM Thomson, AM Murlin, JW Biddle and JM Croom 1972. Salmonella as an index of pollution of surface water. Appl. Microbial. 24:334-339.

15. Bhuiyan AM 1970. Primary production of a fishpond. J. Zool. Rajshahi University 4: 55-58.

16. Barbieri E, L Falzano, C Fiorentini, A Pianetti, W Baffono, P Matarrese, A Casiere, M Katouli, I Kuhn, R Mollby, Bruscol and G Donelli 1999. Occurance, diversity and pathogenicity of Vibrio spp. and non-O1 Vibrio cholerae from estuarine water of the Italian Adriatic coast. Appl. Environ. Microbiol. 65: 2748.

17. Denner EBM, D Vybiral, UR Fischer, B Velimirov and HJ Busse 2000. Calviensis sp. nov., a halophilic, facultatively oligotrophic $0.2 \mathrm{~mm}$ filterable marine bacterium. Int. J. Syst. Evol. Microbiol. 52: 549-565.

18. Kaneko T and RR Colwell 1975. Incidence of Vibrio parahaemolyticus in Chesapeake Bay. Appl. Microbiol. 30: 251-257.

19. Deepanjali A, HS Kumar, I Karunasagar and I Karunasagar 2005. Seasonal variation in abundance of total and pathogenic Vibrio parahaemolyticus bacteria in oysters along the southwest coast of India. Appl. Environ. Microbiol. 71(7): 3575-3580.

20. Neumann DA, H Benemon, E Hubster, $\mathrm{N}$ Thinhutuan and L Tie-van 1972. Vibrio parahaemolyticus in the Republic of Vietnam. Am. J. Trop. Med. Hyg. 22: 464-470.

(Manuscript received on 31 August, 2009; revised on 13 October, 2009) 